\title{
The relation between the self-esteem levels and decision- making styles of the students doing sports and the students not doing sports in high schools
}

\author{
Ozgur GUL, Hakan Salim CAGLAYAN
}

Faculty of Sport Sciences, Selçuk University, Konya, Turkey.

Address correspondence to O. Gul, e-mail: ozgur2003@gmail.com

\begin{abstract}
The objective of this study to determine the self-esteem levels and decision-making styles of the students studying at high schools according to their state of doing and not doing sports and to reveal whether there is a relation between their selfesteem levels and decision-making styles. The research group has been constituted by total 403 students, 114 of whom were doing sports and 289 not doing sports, studying at the high schools acting under Konya Provincial Education Directorate in the first half of the 2014-2015 school year. The group doing sports consisted of the students representing their schools and having taken part in competitions in different branches and the group not doing sports was constituted by the students studying in different departments of the same school and not active in a branch. In the study, as the data collection tool, "Coopersmith Self-esteem Inventory" developed by Coopersmith and adapted to Turkish by Turan \& Tufan as well as "Decision-making Scale in Adolescents" developed by Mann et al. and adapted to Turkish by Çolakkadıoğlu were used. The fact that whether the data were distributed normally or not was scrutinized by the Kolmogorov-Smirnov test and following such scrutiny, as the data were distributed normally, Pearson moment correlation ( $\mathrm{r}$ ) coefficient technique was used to reveal the relation between the self-esteem levels and decision-making styles of students. $\alpha=0.05$ was chosen as the significance level in the study. At the end of the study, it was determined that both the self-esteem levels and decision-making styles of the students doing sports were higher than those who do not do sports. It was ascertained in the students doing sports that there is a relation at moderate level and positive tendency between their self-esteem levels and self-respect in decision-making; at low level and negative tendency between their apathy and avoidance of responsibility decision-making styles, and at moderate level and negative tendency between their panic decision-making styles. In the students not doing sports, a relation at low level and positive tendency in their self-esteem levels and self-respect in decision-making and cautious-selectivity decision-making styles, and at low level and negative tendency between their panic and avoidance of responsibility decision-making styles, was determined.
\end{abstract}

Keywords: Self-esteem, decision-making, sports, high school, student.

\section{INTRODUCTION}

Ego, self, and personality are the concepts that are usually used as synonyms. They connote the organized whole of all the emotions, attitudes, and behaviors that constitute a person. The concept of self is defined as the manner of perceiving and comprehending his/her own self by a person (23).

The layer referred to as "ego" or "self" (the ego, le moi, dasich) that provides the basic traits of personality has been one of the fields on which psychiatrists have worked most in the recent years (14). The concept of self is a concept that covers the existence of a person and the experiences, of which a person is aware by intuition (12).
Self-esteem is the state of liking resulting from the fact that a person appropriates and values himself/herself, feels self-confidence and selfrespect, and approves the concept of self he/she attains as a result of a self-assessment. Self-esteem has a significant place in a person's life, particularly in the adolescence age. The sense of identity acquired in the adolescence age develops in relation with self-esteem (24).

Self-esteem is defined as the source of motivational power. It focuses on the requirement of self-assessment or positive self-assessment by a person. It is specified that social comparisons and reflected evaluations constitute the source for the development of self-esteem. People compare 
themselves with their peers in order to realize their own value. The studies conducted demonstrate that such comparisons are a development fact starting at about the age of seven and intensifying throughout the period of adolescence. It is grouped as high, moderate, and low. Brown (1991) states that people with high self-esteem tend to be happy, healthy, productive, and successful, that they endeavor for a longer time to defeat difficulties, and that the people with low self-esteem expect failures. He adds that they are nervous, they struggle less, they might accuse themselves as "untalented," and they can overlook the important things in life (19).

Cohen (1950) handles self-esteem as the outcome of the experiences of success and failure by a person. Self-esteem is impressed only when such a success or failure is important and meaningful for the respective person. For example, a volleyball player can be very sad and ashamed when he/she misses a critical score in a world championship with a simple mistake while he/she might not be affected to even the slightest extend when he/she is chosen as the worst singer of the world (19).

When the points specified in all these definitions and explanations are brought together, it can be said that the concept of self-esteem consists of the senses of love, respect, and confidence people feel toward themselves by appreciating themselves and accepting their talents and powers through selfrecognition and realistic evaluation (6).

Decision is an appropriate reaction against a situation requiring action. Decision-making is the action of choosing from among many alternatives (10). In lexical meaning, a decision is the final product of the logical process at the end of which doubts and discussions terminate and the chosen way starts to be applied. Decision-making is what we do when we do not know what to do. Decisionmaking is the preference of choosing the one that will provide the highest value between the options (15).

Individuals are considered highly inexperienced to bear the responsibility of decisionmaking in the second decade of their lives. According to Schvaneveldt \& Adams (18), adolescents live in a limited world in reality and their decision-making is not usually supported even in the issues concerning themselves. They cannot vote, look for a job, drive a car, etc.; they cannot act freely in some maters without the consent of the adults. They are both very close to and very far from the position of being an independent adult. The decisions made in the adolescence period have the outcomes that will be affected on an individual's health, psychological adaptation, vocation, and social acceptance throughout his/her life (9). The decisions made in this period might ensure the formation of the appropriate living conditions in the future while they may render such conditions restricted (16).

For a healthy decision-making of an individual, cognitive processes must function. Options must be reviewed and evaluated very well before decisionmaking. Hence, decision-making appears to a person generally as a problem. In a sense, a person must make a decision about what to do in order to solve a problem $(7,8,22)$. The best thing for humans to do is to take the best decision in line with the conditions and the knowledge and to make a new decision for the possible troubling situations (1).

In the light of the foregoing information, the study has been conducted to determine the selfesteem levels and decision-making styles of the students studying at high schools according to their state of doing and not doing sports and to reveal whether there is a relation between their self-esteem levels and decision-making styles.

\section{MATERIALS \& METHODS}

\section{The Model of the Study}

In this study performed complying with the relational screening model, attempt was made to show whether a relation between students' selfesteem levels and decision-making styles is available or not. Relational screening models are the research models aiming to determine the existence and/or the degree of existence of covariance between two and more variables (11).

\section{Population and Sample}

The research group has been constituted by

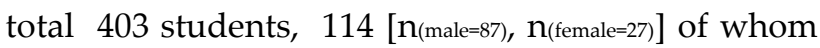

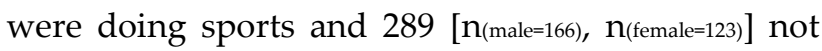
doing sports, studying at the high schools acting under Konya Provincial Education Directorate in the first half of the 2014-2015 school year.

The group doing sports consisted of the students representing their schools and having taken part in competitions in different branches and the group not doing sports was constituted by the 
students studying in different departments of the same school and not active in a branch.

\section{Data Collection Tools}

In the study, as the data collection tool, "Coopersmith Self-esteem Inventory" developed by Coopersmith (4) and adapted to Turkish by Turan \& Tufan (21) as well as "Decision-making Scale in Adolescents" developed by Mann et al. (16) and adapted to Turkish by Çolakkadıoğlu (5) were used.

\section{Coopersmith Self-esteem Inventory}

CSEI (Coopersmith Self Esteem Inventory) has been developed to measure a person's self-views in his/her social, academic, family, and personal lives. In this study, the "school short form" of the inventory was used. In the school short form of the scale, the people responding as "No" to a negative expression and "Yes" to a positive expression receive one point from each question and after summing up all points, the points acquired are multiplied by 4 in order to perform an evaluation upon 100. The school short form consists of the initial 25 points of the school form. The positive expression articles in the school short form are the ones numbered 1, 4, 5, 8, 9, 14, 19, 20 and the negative expression articles are the ones numbered 2, 3, 6, 7, 10, 11, 12,13, 15, 16, 17, 18, 21, 22, 23, 24, 25.

The highest point that might be obtained from the scale is 100 and the lowest one is 0 . Increasing points are in favor of an increase in self-esteem. The self-esteem is "low" if the points received by an individual from the scale are between 10 and 29 points, "moderate" between 30 and 69 points, and "high" between 70 and 100 points (3).

\section{Decision-making Scale in Adolescents}

This scale has been developed by Mann et al (16) in order to determine the self-respect in decision-making and decision-making styles of adolescents. The scale consists of two sections as self-respect in decision-making and styles of coping in decision-making, and of five subscales. There are 30 questions in total (5). The study of adapting the scale into Turkish was performed by Oğuzhan Çolakkadıŏ̆lu, a researcher at Çukurova University, in 2003.

The scale is in four Likert type and the responses given to the articles vary between 0 and 3 points. The scale is scored as "never true for me (0), sometimes true for me (1), often true for me (2), and always true for me (3)." The points that can be received from each subscale are maximum 18 and minimum 0 . The high points received from the subscales show that the respective decision-making style is used. An individual may get high points from several subscales. Only articles 2, 4, and 6 are scored by reversion in the scale. The articles of the subscales of the scale are as follows:

Self-respect in decision-making: 1, 2, 3, 4, 5, 6

Cautious-Selectivity: 8, 13, 16, 20, 23, 27

Apathy: 10, 12, 24, 26, 29, 30

Panic: 11, 15, 18, 19, 22, 25

Avoidance of Responsibility: 7, 9, 14, 17, 21, 28 (5).

\section{Analysis of the Data}

The fact that whether the data were distributed normally or not was scrutinized by the KolmogorovSmirnov test and following such scrutiny, as the data were distributed normally, Pearson -moment correlation ( $\mathrm{r}$ ) coefficient technique was used to reveal the relation between the self-esteem levels and decision-making styles of students. In the construal of the correlation coefficient, the result obtained is considered as a relation at the level of high between 0.70 and 1.00, of moderate between 0.70 0.30 , and of low between $0.30-0.00$ (2). $\alpha=0.05$ was chosen as the significance level in the study.

\section{RESULTS}

It was determined that, of the students doing sports, there is a relation at a moderate level with positive tendency between their self-esteem levels and self-respect in decision-making $(r=0.463 ; \mathrm{P}<0.01)$; at low level with negative tendency between their apathy $(\mathrm{r}=-0.281 ; \quad \mathrm{P}<0.01)$ and avoidance of responsibility $\quad(\mathrm{r}=-0.270 ; \quad \mathrm{P}<0.01)$ decision-making styles, and at moderate level with negative tendency between their panic $(\mathrm{r}=-0.377 ; \mathrm{P}<0.01)$ decisionmaking styles.

It was determined that, of the students not doing sports, there is a relation at low level with positive tendency between their self-esteem levels and self-respect in decision-making $(\mathrm{r}=0.294 ; \mathrm{P}<0.01)$ as well as their cautious-selectivity $(r=0.230 ; \mathrm{P}<0.01)$ decision-making styles and at low level with negative tendency between their panic ( $\mathrm{r}=-0.173$; $\mathrm{P}<0.01)$ and avoidance of responsibility $(\mathrm{r}=-0.150$; $\mathrm{P}<0.01)$ decision-making styles. 
Table 1. The self-esteem levels and decision-making styles of the students doing sports and not doing sports.

\begin{tabular}{|c|c|c|c|c|c|}
\hline Variables & Sub-scales & $\mathrm{n}$ & Mean & SD & $\begin{array}{l}\text { The lowest and highest points that might be } \\
\text { received from the scales }\end{array}$ \\
\hline \multirow{6}{*}{$\begin{array}{l}\text { Students doing } \\
\text { Sports }\end{array}$} & Self-esteem & 114 & 69.47 & 17.31 & $0-100$ \\
\hline & Self-respect in decision-making & 114 & 11.59 & 3.23 & $0-18$ \\
\hline & Cautious Selectivity & 114 & 11.48 & 3.85 & $0-18$ \\
\hline & Apathy & 114 & 6.50 & 3.91 & $0-18$ \\
\hline & Panic & 114 & 7.38 & 3.87 & $0-18$ \\
\hline & Avoidance of Responsibility & 114 & 6.66 & 3.67 & $0-18$ \\
\hline \multirow{6}{*}{$\begin{array}{l}\text { Students not doing } \\
\text { Sports }\end{array}$} & Self-esteem & 289 & 64.52 & 17.38 & $0-100$ \\
\hline & Self-respect in decision-making & 289 & 10.75 & 3.18 & $0-18$ \\
\hline & Cautious Selectivity & 289 & 11.17 & 3.86 & $0-18$ \\
\hline & Apathy & 289 & 6.17 & 3.76 & $0-18$ \\
\hline & Panic & 289 & 7.85 & 3.88 & $0-18$ \\
\hline & Avoidance of Responsibility & 289 & 6.24 & 3.57 & $0-18$ \\
\hline
\end{tabular}

Table 2. The results of the Pearson moment correlation (r) coefficient conducted to determine the relation between the self-esteem levels and decision-making styles of the high school students doing sports.

\begin{tabular}{clccccc}
\hline & \multicolumn{1}{c}{ Self-respect in decision-making } & Cautious Selectivity & Apathy & Panic & Avoidance of Responsibility \\
\hline Self-esteem & $\mathrm{r}$ & $0,463^{* *}$ & 0.175 & $-0.281^{* *}$ & $-0.377^{* *}$ & $-0.270^{* *}$ \\
& $\mathrm{p}$ & 0,000 & 0.062 & 0.002 & 0.000 & 0.004 \\
& $\mathrm{n}$ & 114 & 114 & 114 & 114 & 114 \\
\hline
\end{tabular}

Table 3. The results of the Pearson moment correlation (r) coefficient conducted to determine the relation between the self-esteem levels and decision-making styles of the high school students not doing sports

\begin{tabular}{ccccccc}
\hline & & $\begin{array}{c}\text { Self-respect in } \\
\text { decision-making }\end{array}$ & $\begin{array}{c}\text { Cautious } \\
\text { Selectivity }\end{array}$ & Apathy & Panic & $\begin{array}{c}\text { Avoidance of } \\
\text { Responsibility }\end{array}$ \\
\hline Self-esteem & $\mathrm{r}$ & $0.294^{* *}$ & $0.230^{* *}$ & -0.091 & $-0.173^{* *}$ & $-0.150^{*}$ \\
& $\mathrm{p}$ & 0.000 & 0.000 & 0.124 & 0.003 & 0.011 \\
& $\mathrm{n}$ & 289 & 289 & 289 & 289 & 289 \\
\hline
\end{tabular}

\section{DISCUSSION}

Following results have been obtained in this study conducted to determine the self-esteem levels and decision-making styles of the students studying at high schools according to their state of doing and not doing sports and to reveal whether there is a relation between their self-esteem levels and decision-making styles:

In terms of the average points relating to the self-esteem levels and decision-making styles of the students doing and not doing sports, it was determined that both the self-esteem levels and decision-making styles of the students doing sports were higher than those not doing sports (Table 1). According to this result, it is possible to say that the physical energy increasing particularly in the adolescence period is canalized in the best manner in favor those who do sports and that the impact of sports is important in students' possession of a healthy concept of self and in their positive opinions about themselves. Also according to the foregoing result obtained, we can say that self-confidence of the students doing sports is at higher levels than the students not doing sports on the decision-making stage; in other words, doing sports is an important 
factor in individuals' self-confidence on their decision-making stage.

In a research where the self-esteem points of the students taking part in summer sports schools, a statistically significant difference between the overall self-esteem, social self-esteem, academic selfesteem, and pretest and final test total points of the students taking part in summer sports schools (13). In addition, in a study conducted by Taşgit (20), the difference between the self-respect levels of the university students doing and not doing sports in their decision-making was ascertained as significant. It was also determined that the self-respect and selfconfidence levels of the students doing sports were higher than the students not doing sports in their decision-making. These findings are supportive of the results of our study.

It was determined that, of the students doing sports, there is a relation at a moderate level with positive tendency between their self-esteem levels and self-respect in decision-making; at low level with negative tendency between their apathy and avoidance of responsibility decision-making styles, and at moderate level with negative tendency between their panic decision-making styles (Table 2). According to this result, we can say that in parallel with the increase in the self-esteem levels of the students doing sports, their self-respect in decision-making levels will increase and the levels of using the apathy, panic and avoidance of responsibility decision-making style will decrease.

It is a known fact that in the periods of childhood and adolescence, in which the personality, self, and self-esteem develop along with their depressions and hardships and which constitutes a significant part of human life, individuals are in a rapid development and change physically and psychologically. Such change has direct impact on the self and self-esteem with physical activity and motor performance level. It is necessary to expand sports in all walks of a society, to raise awareness, and to provide the required means to be able to grow healthier generations with self-confidence and high self-esteem.

It is known that the behavior of avoidance of responsibility flourishes in the environments where sufficient care is not acquired or whatever a child must do is undertaken by the parents through excessive tolerance. The adolescents growing up in the ambiances where such behaviors are exhibited can have similar expectations in their lives outside the family. Expectations and habits will affect the decision-making mechanism of an individual. However, the sportive activities performed especially in the adolescence period, presence of sportive environments, as well as the unbroken support from friends and teachers and willingness for not being forfeited prevent such decisions that are in the form of fleeing responsibility.

Radford et al (17) determined in their study performed to search for the relation between cultural difference and decision-making styles of university students that those students with high self-respect in decision-making experience less decision stress and that they exhibit behaviors with more tendency toward using their selection and responsibility styles. Above remark and the findings of this study are supportive of our study.

It was determined that, of the students not doing sports, there is a relation at low level with positive tendency between their self-esteem levels and self-respect in decision-making as well as their cautious-selectivity decision-making styles and at low level with negative tendency between their panic and avoidance of responsibility decisionmaking styles (Table 3). According to this result, we can say that in parallel with the increase of the selfesteem levels of the students not doing sports, their self-respect in decision-making levels and cautiousselectivity decision-making styles will also increase and their levels of utilizing the panicand avoidance of responsibility decision-making style will decrease.

As a result, it was determined that both the selfesteem levels and decision-making styles of the students doing sports were higher than those who do not do sports; that, of the students doing sports, there is a relation at a moderate level with positive tendency between their self-esteem levels and selfrespect in decision-making; at low level with negative tendency between their apathy and avoidance of responsibility decision-making styles, and at moderate level with negative tendency between their panic decision-making styles; and that, of the students not doing sports, there is a relation at low level with positive tendency between their self-esteem levels and self-respect in decisionmaking as well as their cautious-selectivity decisionmaking styles and at low level with negative tendency between their panic and avoidance of responsibility decision-making styles. 


\section{REFERENCES}

1. Adair J. Karar Verme ve Problem Çözme. (Çev: Kalaycı N.), Edit: Atay M.T., Ankara: Gazi Kitabevi, 2000.

2. Büyüköztürk Ş. Data Analysis Handbook for Social Sciences. Ankara: Pegem A Yayıncilik, 2007.

3. Coopersmith S. Self-Esteem Inventories. Consulting Psychologist Pres, Inc. 3803 E. B. Ayshore Road, Palo Alto, CA 94303, 1991.

4. Coopersmith S. The Antecedents of Self-Esteem. San Fransisco: W.H. Freeman and Company, 1974.

5. Çolakkadıŏ̆lu O. Ergenlerde Karar Verme Ölçeği'nin Uyarlama Çalışması. Yayınlanmamış yüksek lisans tezi, Çukurova Üniversitesi Sosyal Bilimler Enstitüsü, 2003.

6. Çuhadaroğlu F. Adolesanlarda Benlik Saygısı. Yayınlanmış Uzmanlık Tezi, Hacettepe Üniversitesi Tıp Fakültesi, Ankara, 1986.

7. Deniz, M.E. Investigation of the relation between decision making self-esteem, decision making style and problem solving skills of university students. Eurasian Journal of Educational Research, 2004; 15: 23-35.

8. Eldeleklioğlu J. Karar stratejileri ile ana-baba tutumlari arasindaki ilişki. Unpublished Doctoral Thesis, Gazi University, Institute of Health Sciences, Ankara, 1996.

9. Ersever, Ö.H. Karar verme becerileri kazandirma programinin ve etkileşim grubu deneyiminin üniversite öğrencilerinin karar verme stilleri üzerindeki etkileri. Unpublished Doctoral Thesis, Ankara University, Institute of Social Sciences, Ankara, 1996.

10. İlmez M. Bir kamu kurumundaki görevli yöneticilerin ve çalışanların liderlik stilleri ile karar verme stilleri arasındaki ilişkinin belirlenmesi. Unpublished Master Thesis, Ufuk University, Institute of Social Sciences, 2010.

11. Karasar N. Bilimsel Araştırma Yöntemi. Ankara: Nobel Yayıncilık, 2004.

12. Kasatura İ. Kişilik ve Özgüven Psikoloji Dizisi 4. İstanbul: Evrim Yayınları, 1998.
13. Korkmaz HN. Yaz spor okullari ile çocuklarin benlik saygisi arasindaki ilişki. Uludağ University J Education Faculty, 2007.

14. Köknel Ö. Kaygıdan Mutluluğa Kişilik. İstanbul: Altın Kitapevi, 1985.

15. Kurt Ü. Karar verme sürecinde yöneticilerin kişilik yapılarının etkileri. Başkent University, Institute of Social Sciences, Ankara, 2003.

16. Mann L, Harmoni R, Power C. Adolescent decision-making: The development of competence. Journal of Adolescence, 1989; 12(3): 265-278.

17. Radford MHB, Mann L, Ohta Y, Nakane Y. Difference between Australian and Japanese students in reported use of decision processes. International Journal Psychology, 1991; 26: 35-32.

18. Scvaneveldt YD, Adams GR. Adolescents and the decision making process. Theory into Practice, 1983; 22(2): 98-104.

19. Sevinç M. Erken Çocuklukta Gelişim ve Eğitimde Yeni Yaklaşımlar. 1. Baskı, İstanbul: Morpa Kültür Yayınları, 2003.

20. Taşgit MS. Üniversite öğrencilerinin benlik saygısı ve karar verme düzeylerinin incelenmesi. Unpublished Master Thesis, Karamanoğlu Mehmet Bey University, Institute of Social Sciences, Karaman, 2012.

21. Turan N, Tufan B. Coopersmith Benlik Saygisı Envanteri'nin (SEI) Geçerlik-Güvenirlik Çalışması. İstanbul: In: 23. Ulusal Psikiyatri ve Nörolojik Bilimler Kongresi; 1987; 816-817.

22. Yeşilyaprak B. Eğitimde Rehberlik Hizmetleri Gelişimsel Yaklaşım. Ankara: Nobel Yayın Dağıtım, 2003.

23. Yiğit H. Ergenlerin benlik saygılarının yaşam doyumu ve bazı özlük nitelikleri açısından incelenmesi. Unpublished Master Thesis, Selçuk University, Institute of Education Sciences, Konya, 2010.

24. Yörükoğlu, A. Gençlik Çağı Ruh Sağlı̆̆ı Eğitimi ve Ruhsal Sorunları. 5. Baskı, İstanbul: Türkiye İş Bankası Kültür Yayınları Sosyal ve Felsefi Eserler Dizisi, 1988. 